\title{
PECREATIVITY | PEOPLE ECONOMY CITY: THE CASE OF LONDON AS A PROACTIVE INVESTIGATION TOOL
}

\author{
Giuliana BONIFATI* \\ Politecnico di Milano, Department of Architecture and Urban Studies, \\ Via Edoardo Bonardi, 3, Milano 20 133, Italy
}

Received 28 April 2017; accepted 19 June 2018

\begin{abstract}
The current historical context is characterised by a significant change in the economic and social fields that have led to the development of the economy of creativity and knowledge. This condition has laid the basis for the rise of a new social class. This radical change in the productive paradigm has started a series of modifications to urban spaces, setting in place a rooted change in the fabric of the city.

The objective of this paper is to understand and interpret the nature of the changes under way and to investigate how what occurred in economic and social fields influenced the processes of urban regeneration. Starting from a theoretical background it will examine the concept of creativity applied to economics and social sciences. Secondly, by identifying the urban environment of London as a case study, it will analyze single cases that will show the root of these practices within urban spaces. The purpose of it will be verified by the possibility of building urban transformation strategies that use creativity as the tool of change.
\end{abstract}

Keywords: creative city, creative economy, creative process, creative society, creativity, urban design, urban studies.

\section{Introduction}

The historical context in which we live is characterised by a deep-rooted change in the economic and social value system. Since the crisis in the manufacturing sector, which took place during the dying decades of the last century, there has been a rapid shift of economic value from material goods to the non-material ones. This change has deeply undermined the paradigm of production. Until that time the production process was based on the development of durable products for mass consumption, with the change of values it has placed at its centre knowledge, ideas and creativity. The fall in manufacturing followed by the subsequent financial crisis, caused the collapse of the world's economy, at the same time resulting in a change in society. We are facing the gradual growth of a new social class, the so-called

*Corresponding author. E-mail: giuliana.bonifati@gmail.com 
creative class. As a result, the roots of the creatives within cities have triggered a series of urban space modification processes.

The aim of the paper is to analyse the nature of these economic and social changes and their roots within the contemporary city. In particular, the objective is to investigate and understand how the city has developed as a result of economic and social change and how creativity contributes to the transformation of urban spaces. After the analysis of the economic and social changes, the questions will be orientated towards the role of urban designers in the process. The goals are firstly to understand how the creative transformation takes root in the city; secondly to define strategic models to manage the change. The analysis will be addressed by taking into consideration different supporting issues: firstly, it will examine the conditions of the historical context, highlighting the needs that have led to the change and its own nature. Secondly, it will study in depth the theoretical background in economic and social terms and, finally, the third section will be devoted to the modification of urban spaces and urban practices rooted in London as case studies which underline the main transformations happening in the contemporary city.

Taking the city of London as a study and research tool will allow not only to understand how the creative process is taking root in a global city and according to what characteristics, methods, and types are developed, but also wants to be expedient in order to understand if there is the possibility to take the British example as an application model to be proposed in other contexts.

The aim is indeed to understand how the process is developing and how much the designer needs to change the point of view and find new ways to approach the process itself. The case study is therefore considered as a proactive tool of investigation rather than a storytelling.

\section{The nature of the change}

In order to analyse creative transformations in the scientific disciplines considered, it is appropriate to specify the way the word creativity is understood and what is meant by creative process. John Howkins opens his work The Creative Economy: How People Make Money from Ideas with this question: "who is creative, and why?" (2001, vii). The answer seems very simple: "everyone who has ideas is creative" (Howkins, 2001, vii). However, the reality is more complex because the modification of the production paradigm has placed ideas at the centre of the economic power. People with ideas have become more powerful than people who work machines. In this sense, the idea becomes a source of profit. Companies want to hire people who have ideas. The comparison between Kodak and Facebook is a notable and impressive example. In the 1980s Kodak was a high-tech company with the largest turnover in the United States and employed a diverse workforce including engineers, technicians and workers. Nowadays Facebook, considered one of the largest high-tech companies in the world, hires only young people with high levels of education (Moretti, 2016).

Bringing ideas into the heart of the production process creates a tool for finding more and more relationships between creativity, business and money. In this way, the creative process takes place and develops using an idea, giving it a new meaning and understanding 
of how it can be used to produce another idea. For this reason the concept of creativity is closely linked to the production of ideas and it is at the centre of economic strength within the contemporary historical context. But it is not enough simply to produce the idea to drive the process: one of the dominant features of the creative class, in addition to the production of ideas, is to be able to manage them (Howkins, 2001, p. 45).

During the period between the manufacturing crisis and today, two important industrial revolutions have occurred in the world and have taken root very rapidly. The advent of the personal computer has favoured the birth of a financial market which, in its turn, has caused a severe crisis in the industries producing durable goods. In the same way, the financial crisis of 2007-2008 caused the collapse of larger multinational companies and global markets, allowing space for new ideas originating in local markets and start-ups. The result is that we are facing a rapid and progressive shift in the economic value that moves evermore towards the production of intangible and non-material assets.

These economic revolutions had severe consequences for the society and urban spaces: the so-called blue-collar workers are soon replaced by white-collar workers and the latter by an increasingly digital society. The digital-technological progress has profoundly modified the productive process, from being a chain system, characterised by mounting activities that provide a precise sequence of industrial executions, to a "cobweb system" (Bonomi, 2010, p. 27). This system provides an extension of the process steps and actors involved, depending on the requirement of the end user that may change from time to time. The digital presence allows a continuous interaction and the networked exchange of information, ideas and cognitive skills. The new world, characterized by the interconnection of digital life with the physical life (Schwab, 2016, p. 123), leads to a society that unravels more and more relationships between the material and the virtual, reflecting the change in all sectors of life. An illustration is the data that lead to the world's digital presence in social terms: the majority of the world's population is now connected via several profiles on online platforms (Figure 1). In this way, if we look at the transformation from a perspective aimed at places, it is absolutely identifiable as these social and economic practices become entrenched within the global city spaces.

\section{Top 10 Populations ('000,000)

$\begin{array}{rrlr}\mathbf{1} & \mathbf{f} & \text { Facebook } & \mathbf{1 , 4 0 0} \\ \mathbf{2} & & \text { China } & 1,360 \\ \mathbf{3} & & \text { India } & 1,240 \\ \mathbf{4} & & \text { Twitter } & \mathbf{6 4 6} \\ \mathbf{5} & & \text { USA } & 318 \\ \mathbf{6} & & \text { Indonesia } & 247 \\ \mathbf{7} & \text { Brazil } & 202 \\ \mathbf{8} & \mathbf{C} & \text { Pakistan } & 186 \\ \mathbf{9} & & \text { Nigeria } & 173 \\ \mathbf{1 0} & \text { Instagram } & \mathbf{1 5 2}\end{array}$

Figure 1. Active users of social media compared with the populations of the world's largest countries (source: mccrindle, 2015) 


\section{Working spaces and urban practices}

Despite the increasingly rooted digital life and virtual communication, interaction and physical networking remain indispensable (Landry, 2008, p. 34), which trigger a close relationship between global and local who sees the place as an exchange device between physical and digital life. For this reason, the city plays a decisive role in the spread of these practices, as is defined as a hub that "provides conditions for change and diversity, generating fashions, entertainments and glamor" (Howkins, 2001, p. 209). The spaces in contemporary cities foster the exchange of information, ideas and knowledge, becoming the privileged place for the establishment of new digital and creative industries. This condition which makes it an attractive urban space and fertile place, radically change its assets. The city, or parts of it, is faced with a complete transformation at the base of which the creative process arises.

The crisis in the manufacturing sector has caused a rapid abandonment of the spaces dedicated to the production, such as factories, warehouses, depots and workshops. These spaces, previously belonging to the industrial suburbs, have been incorporated into the expansion of the city and are the ideal place for the settlement of new digital industries and start-ups. Their lower price, owing to their abandonment, as well as the close proximity to the inner city encourages creative young people to settle in these areas.

The reconfiguration of the spaces of the old industries is driving a process of rebirth in some areas of the city that the crisis had made them forget. In this sense the physical and social restratification offers an ever-increasing development of residential neighbourhoods, commercial activities and services to occupy and reactivate these places. Spatial and social diversity contributes to the development of diversified areas of work, life and leisure. Public spaces are converted into places of recreation for the exchange of knowledge, leading to the development of a new economic model based on dependency and competition of urban spaces. The overlapping and layering of spaces for production, distribution and consumption, public spaces and houses define a multi-layer system capable of significantly modifying the image of parts of the city.

The emerging digital media industries are designed to be placed in the form of clusters in certain urban locations: the dynamics that are being set up in certain urban areas are closely linked to the organization and production processes (Martins, 2015, p. 127). The production process of the new economic form, in fact, constitutes the different phases of the work, some strictly formal and active, others characterised by complementary activities, such as socializing and the exchange of ideas. These complementary activities contribute to building a network of collateral relations. The following work dimension has profoundly changed the nature of working spaces, which have been necessary to create new spaces dedicated to complementary integrative activities. The place of production is no longer identified as a single space, but is configured as an extended space which also includes public and semi-public spaces. These spaces, which are identified in cafes, restaurants, libraries, areas of co-working, squares, markets, temporary shops, etc., play a crucial role as complementary places within the main workspace and their use is occasional and associated with particular activities. Working in a digital industry does not require particular physical conformation of the working space. The increasingly innovative technological developments enable access to the data and productions directly from mobile devices. For this reason the new digital industries are often located in private homes or in places that share other uses of space. Therefore the role of complementary places, which 
are often more appropriate for activities that include social aspect: for example promotion and delivery of the product; meeting with other individuals for both informative reasons and exchange of knowledge, is important. It follows that whole parts of the urban fabric, both opened and closed spaces, from public spaces to private ones, become the stage of the new productive class. Each space contributes to being the place of birth, proliferation and distribution of new ideas, returning to the image of a creative and productive cluster to the city. At the same time, the continuous and diversified use of space makes the city a real urban workshop.

\section{London as creative city}

Cities provide for the construction of an inspiring and fertile environment for creativity, offering facilities, scenes, and ecosystems capable of attracting talent from outside, who are looking for a high-quality level of experiences, great openness, and tolerance towards diversity and high opportunity to express their abilities. And in this sense cities have always been the driving force for the development of economies based on culture and knowledge, contributing to be the hub of creativity and build an environment for the development and growth of creative practices related to innovation and knowledge.

London has historically been a fertile place concerning the creative industries: great centre of intellectual and cultural production has quickly become one of the largest cities in Europe attractor of artists and musicians. Nowadays London is considered one of the dominant city in the world economy and one of the key cities in the production of cultural goods (Lee \& Drever, 2012, p. 1977; Pratt, 2006, 2009; Sunley, Pinch, Reimer, \& Macmillen, 2008; Comunian, 2011), which is a fundamental part of the city economy: Alan Freeman (2010) has estimated that in 2007 almost 400000 persons were engaged in the creative industry in London (Lee \& Drever, 2012, p. 1977). The density of the city supports and promotes the exchange of knowledge and enables the transmission and sharing between individuals, furthermore, the city provides access to different institutions and cultural sites, such as galleries, museums, theatres that stimulate creative people to enter and establish in a cultural context of such turmoil.

During the final decades of the last century London witnessed regeneration and urban transformation processes as a result of artistic movements that have spread in some parts of the city. Attracted by the strong cultural and intellectual potential of the city, groups of artists have settled in the less expensive areas of the city for over 40 years, within a context in which each of them has developed and implemented their own creative talent. The need to exchange knowledge and cultural ideas has contributed to the definition of these spontaneous settlements which have led to profound changes in the economy, society and spaces within the city. The artistic invasion in those city areas forgotten and/or undeveloped have led to the rebirth of places and given drive to the development of support services and facilities, such as cafes, restaurants and shops. In this way areas such as Soho, Camden Town, London Borough of Hackney and London Borough of Tower Hamlets have become the focus of many large companies and start-ups at both national and international levels (Landry, 2008, p. 124). Companies in turn attract and involve a large number of clients and collaborators from outside, who have established themselves in the area. Many of these interventions spontaneous and uncontrolled, transforming the city with no programme of change or, indeed, any control. For some years, however, this issue has become the subject of discussion not only 
within professional circles, such as architecture and urban design, but also in administrative contexts and local government. This has led to the development of urban transformation programmes and plans that see cultural and creative activities as the centre of the process and the goal of the change. In particular, creativity is increasingly becoming a central theme in the architectural and urban design debate of several architectural practices in the East End of London, which develop creative regeneration projects in under-used places or places in a state of degradation, through bottom-up and participation processes. These processes have the ability to trigger multi-disciplinary approaches and to work not only on the spatial dimension of the place but equally on the economic and social dimension.

From this derives a great change in the architectural approach and in the role of the designer within the process, as it assumes in this context not only the task of planning and design but also, in particular, the task of managing and controlling.

\section{Discussion}

The economic, social and spatial transformation that is deeply rooted in London very quickly resulted in an uncontrolled regenerative process with no concept of planning. For this reason, it is necessary to inquire about how these processes have actually spread and how the urban designer takes part in the process.

Parts of the city, such as Shoreditch, in the East End of London, are faced to a process triggered through spontaneous practices caused by a segment of the population, from the artistic movements at the turn of the century, up to the most current East London Tech City.

Cases like Pop Brixton (Figure 2), in South London or Dalston, also in the East End of London, instead, were developed following a strong community presence particularly connected to the need for spaces for developing small local economies. In these cases the transformation has created entire pop up spaces for jobs, businesses and leisure amenities, which have had the strength to regenerate entire neighborhoods formerly degraded and inactive.

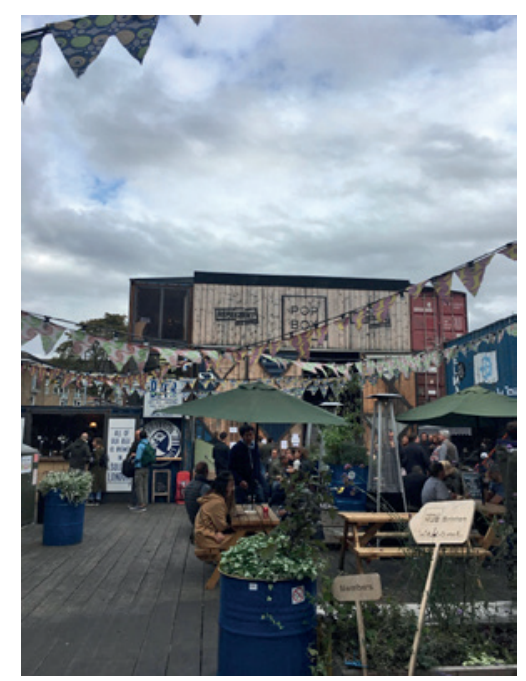

Figure 2. Pop Brixton, London (source: created by author, 2017) 
Other cases, such as Hackney Wick or the area of Kings Cross, are characterised by great planned interventions have favoured the rebirth of the area and the creative reactivation of adjacent places. The construction of the Queen Elizabeth Olympic Park in 2012 caused a drastic schism in the Hackney Wick area (Figure 3). On the one hand this resulted in an increase in the economic value of the area, but on the other hand has significantly destroyed the image of the place.

In this kind of contexts we can read different types of creative process which taken root within the urban settlement and totally changed the image of the city. The most interesting thing we are facing on and that should need the attention of designers is the dynamic by which the gentrification process takes place in London. The big difference spotted in the City belongs to the capability of spontaneous actions to generate vital processes. Most times the gentrification gather from minimal intervention and change led by people and not planned by practitioners who seem to have lost his main responsibility within the urban regeneration process. In this regard the main question to ask is how designers could find a role inside this kind of gentrification processes and how the urban regeneration project could change approach facing on this modified context.

From this point of view London offers a corollary of case studies that make it and its spaces a real creative workshop. The creative needs came from the economic and social change that were the thrust in defining new settlements, whose physical spaces were the perfect answer to their needs.

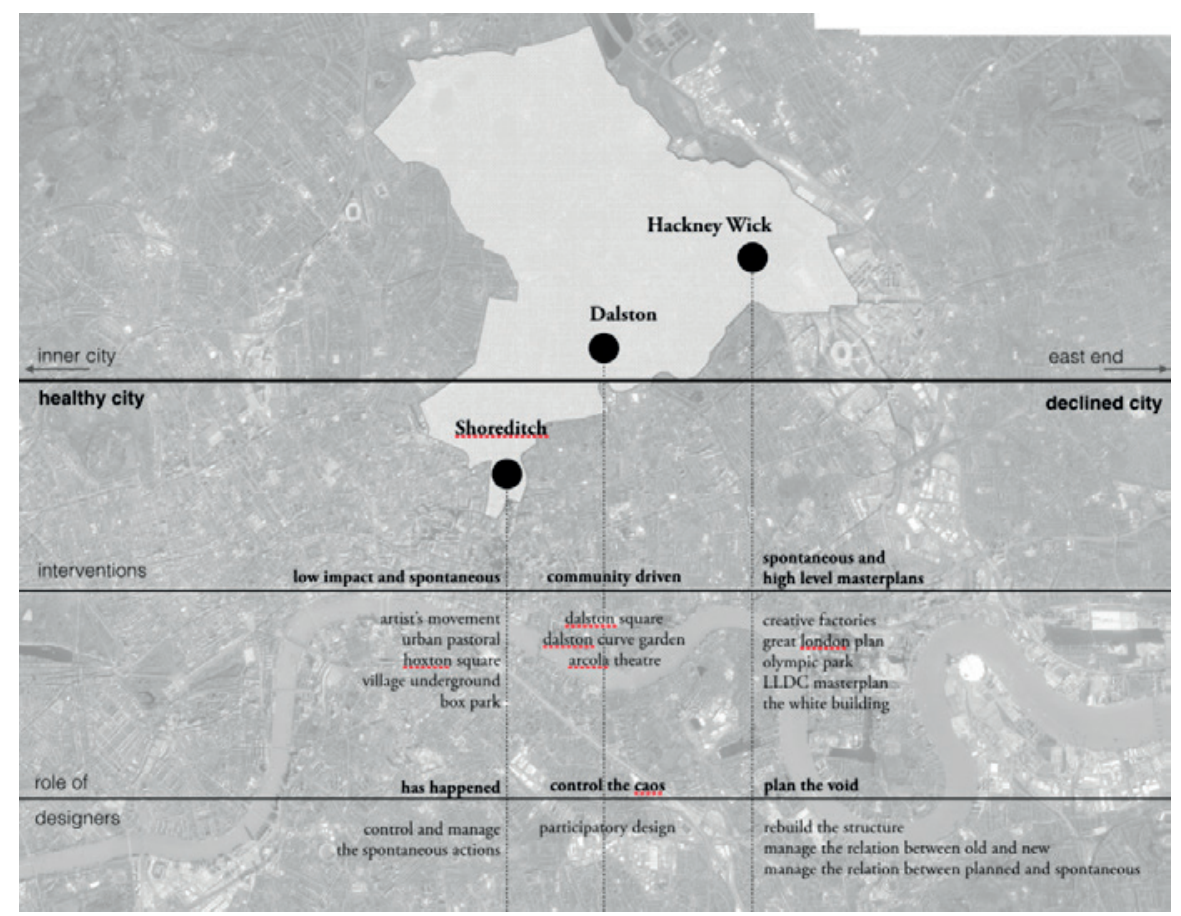

Figure 3. Strategic interpretation of the case studies. London Borough of Hackney (source: created by author, 2017) 
The interdisciplinary relationship that links these changes highlights the potential of the concept of creativity as a tool for transformation. Taking into consideration London's cases, it is easy to find a drastic difference in the nature of the interventions, within which the urban designer often assumes a marginal or null role. We are facing diversified and interdisciplinary processes: the actors who take part are heterogeneous and cannot be categorized into a single group of people belonging to a specific category. What is common to the different figures that come into play is the creative potential, and the need to express it, that is specified in a particular productive sector but which as a whole is multidisciplinary.

The issue on which now demands our focus is the possibility and the need to build strategic models of creative regeneration that see the active role of practitioners in the process. Re-positioning this focus means being able to build applications and programmatic strategies that allow us to move away from the traditional urban design approach that over-imposes a form-functional masterplan of enormous size and long run times. The case of Shoreditch leads to the realization that the urban fabric is able to be regenerated and reactivated radically without necessarily using strong-intensity transformative tools. The cases of Pop Brixton and Dalston return us to the driving force of the local communities as a tool for transformation. The process develops, often imperceptibly, from the bottom up, by way of minimum and weak actions. In such a context the imposition from above of a project could result in loss of balance. Rather, what is missing and what is needed is the control and management of change.

Hackney Wick requires more controlled interventions, able to change not only the use of the spaces but also to manage its settlement structure to re-connect its infrastructure between the "new" to the "old", in a continuous exchange between "controlled" and "spontaneous". The practitioner should be called to direct the transformation process in terms of space and time, checking the appropriateness of the bottom-up actions in a development and urban regeneration context, by analyzing and studying the effects they have on the site, identifying what is working and what needs to be redirected. Identifying what is missing and develops maintenance and integration plans in order to establish a solid base to be able to respond to subsequent amendments.

Considering London as an example to study and to learn the creative process within the transformation of urban asset, the question is whether could be also possible consider the City as a model to be applied to other cities. Breaking up the creative urban transformation process it is possible identify too many similarities between the processes however each creative process has used to be unique and untransferable. For this reason to answer to the question above we need first of all to acknowledge economical and social conditions of London that were and are totally different from other European cities. Nevertheless it might be possible to build a methodological approach to investigate, study, to break up the process in order to understand from where the process started and toward where is developing in a such way as to define what is missing. Furthermore it might be possible to build consider the case of London an experimental workshop to build a sheet of possible design actions divided by categories to apply in similar context. 


\section{Conclusions}

The history of London and the transformation of some of its areas put the conditions to think over a general mutation spreading in our urban spaces and in our society. The power market is moving toward different values, for the first time linked to the intellectual property and work of thinking. For this reason everything is going back to the human scale in terms of accessibility and priority. As a consequence, the spaces of our cities are changing in the same direction, toward lower impact and spontaneous transformations frequently "just happened".

This context of continuous mutation has put in crisis the way how to design our cities; the urban designer has asked to face on a different approach to follow the change and in some cases has lost his traditional role. The challenge, on what this article is focus on, is to give attention on the entire regeneration process and find a way to build a common strategy for the modification. To give to designers the condition to think different and find a new role within the project.

This article would be the starting point of a deeper research about new approaches to the urban design; the case study showed how much the contemporary city is in an ongoing transformation in most cases without a kind of control and for this reason the question how the designer can find a new way to get involved into the urban transformation?, seems to be the first grade to get awareness of the change. Furthermore, understanding in depth the nature of the change as well as how the transformation is driven is the outstanding starting point to develop new solutions and way of approaching the creative urban transformation process.

Creativity is the engine with which these processes have taken root in our city but at the same time could be a way to rethink the urban space. Following the dynamic that are spreading spontaneously, understanding how the creative process moves into spaces, it is possible to recognize creativity as the toolkit to guide the transformation. In this sense the practitioner acquires the role of the film director within the urban contemporary theatre (Jacobs, 1969).

Therefore, this paper would not argue absolute and firmed answers to the topic rather it wants to be the basis for a wider research which opens to propose actual and proper design strategies and tools throughout following investigations, practical exercises and publications.

\section{Acknowledgements}

The author would like to thank Professors Carlos Garcìa Vázquez and Peter Bishop together with Dr. Pablo Sendra for the constant support and guidance in the research and the time they have devoted to the revision of this paper. Furthermore she thanks Professor Tomas Kačerauskas for the opportunity within the conference "Creative Society: Ideas, Problems and Concepts" and the purpose of the same paper publication. Another thank goes to the publisher for the availability gave in the publication of the paper.

\section{References}

Bonomi, A. (2010). La città che sente e pensa: Creatività e piattaforme produttive nella città infinita. Milano: Mondadori Electa.

Comunian, R. (2011). Rethinking the creative city: the role of complexity, networks and interactions in the urban creative economy. Urban Studies, 48(6), 1157-1179. https://doi.org/10.1177/0042098010370626 
Freeman, A. (2010). London's creative workforce: 2009 update. GLAEconomics: Working Paper 40. London: Greater London Authority.

Howkins, J. (2001). The creative economy: how people make money from ideas. London, Penguin.

Jacobs, J. (1969). Vita e morte delle grandi città. Saggio sulle metropoli americane. Torino: Einaudi.

Landry, Ch. (2008). The creative city: a toolkit for urban innovators. London and Sterling, VA: Earthscan.

Lee, N., \& Drever, E. (2012). The creative industries, creative occupations and innovation in London. European Planning Studies, 21(12), 1977-1997. https://doi.org/10.1080/09654313.2012.722969

mccrindle. (2015). Social media and narcissism. Retrieved from http://mccrindle.com.au/the-mccrindleblog/social-media-and-narcissism

Martins, J. (2015). The extended workplace in a creative cluster: exploring space(s) of digital work in Silicon roundabout. Journal of Urban Design, 20(1), 125-145. https://doi.org/10.1080/13574809.2014.972349

Moretti, E. (2016). Il neolavoro: La creatività è il vero capitale. La creatività è il vero capitale. Le fabbriche si spostano o si svuotano: Conoscenza e talento generano reddito. Corriere della Sera, Domenica 21(Febbraio 2016), 54-55.

Pratt, A. C. (2006). Advertising and creativity, a governance approach: a case study of creative agencies in London. Environment and Planning A: Economy and Space, 38(10), 1883-1899. https://doi.org/10.1068/a38261

Pratt, A. C. (2009). Urban regeneration: from the arts "feel good" factor to the cultural economy. A case study of Hoxton, London. Urban Studies, 46(5-8), 1041-1061. https://doi.org/10.1177/0042098009103854

Schwab, k. (2016). The fourth industrial revolution. Cologny/Geneva: World Economic Forum.

Sunley, P., Pinch, S., Reimer, S., \& Macmillen, J. (2008). Innovation in a creative production system: the case of design. Journal of Economic Geography, 8(5), 675-698. Retrieved from http://www.techcitymap.com/index.html\#/

\title{
PECREATIVITY | ŽMONIŲ EKONOMIKOS MIESTAS: LONDONO KAIP INICIATYVIOJO TYRIMO PRIEMONĖS ATVEJIS
}

\author{
Giuliana BONIFATI
}

\section{Santrauka}

Dabartinị istorinị kontekstą apibūdina reikšmingos ekonominių ir socialinių sričių permainos, nutiesusios kelią kūrybiškumo ir žinių ekonomikos plètrai. Ši sąlyga suformavo pagrindą iškilti naujai socialinei klasei. Šis radikalus produktyvios paradigmos pokytis lemė daugelio miesto erdvių modifikacijų pradžią, įtvirtinant įsišaknijusią permainą miesto struktūroje.

Šio straipsnio tikslas - suprasti ir interpretuoti vykstančių permainų pobūdị, ištirti ekonomikos ir socialinių sričiu permainų ítaką miestų atgaivinimo procesams. Pradedant teoriniu pagrindu tiriamas kūrybiškumo konceptas, taikomas ekonomikai ir socialiniams mokslams. Antra, identifikuojant tyrimo atvejo Londono aplinką, analizuojami paskiri atvejai, atskleidžiantys šių praktikų miesto erdvese pagrindus. Straipsnio tikslas - patikrinti galimybę sukurti miesto transformavimo strategijas, kurių atveju kūrybiškumas pasitelkiamas kaip permainos priemonè.

Reikšminiai žodžiai: kūrybinis miestas, kūrybos ekonomika, kūrybos procesas, kūrybos visuomenė, kūrybiškumas, miestų projektavimas, miesto studijos. 